\title{
Robotic Total Hysterectomy: Initial Experience in a Tertiary Center
}

\author{
Robotik Total Histerektomi: Tersiyer Bir Merkezin IIlk Deneyimi
}

Alper Biler, Ulas Solmaz, Mehmet Gokcu, Emre Mat, Atalay Ekin, Ahmet Demir

Tepecik Training and Research Hospital, Department of Obstetrics and Gynecology, Izmir, Turkey

\section{ABSTRACT}

Objective: To examine our initial experience with robotic total hysterectomy and evaluate operation related outcomes.

Materials and Methods: We retrospectively analyzed 16 consecutive patients who underwent robotic total hysterectomy between December 2015 and August 2016 in our clinic.

Results: Robotic total hysterectomy was performed for benign indications in $13(81.25 \%)$ patients, endometrial cancer in two patients $(12.5 \%)$, microinvasive cervical cancer in one patient $(6.25 \%)$. The mean age of patients was $48.7 \pm 6.5$ years, parity was $2.8 \pm 1.7$, body mass index was 28.2 $\pm 4.6 \mathrm{~kg} / \mathrm{m} 2$, preoperative hemoglobin levels was $11.6 \pm 1.0 \mathrm{~g} / \mathrm{dl}$, postoperative hemoglobin levels $10.3 \pm 1.0 \mathrm{~g} / \mathrm{dl}$, operation time was $162.2 \pm$ 39.4 minutes, docking time was $7.3 \pm 3.3$ minutes, console time was $147 \pm$ 37.0 minutes, uterine weight was $178.8 \pm 98.5 \mathrm{~g}$ and duration of hospital stay was $3.6 \pm 1.8$ days. Blood transfusion was administered to three patients in the postoperative period. One patient was converted to laparotomy because of poor visualization of pelvic structures by a large uterus. No intraoperative complication was encountered. Postoperative complications were limited to one patient with asthma who had fever on the first day following surgery. Conclusion: The results of robotic total hysterectomy is satisfactory for both patient and surgeon. Following the completion of the learning curve, robotic total hysterectomy could be an important alternative method for laparoscopic hysterectomy. However, the installation of robotic systems, operating and maintenance costs still remain as crucial limitations for the widespread use of robotic surgery.

Key Words: Robotic total hysterectomy, da Vinci, laparoscopic hysterectomy

Received: 12.20 .2016

Accepted: 02.14.2017

\section{ÖZET}

Amaç: Robotik total histerektomi ile ilk deneyimimizi incelemek ve operasyonla ilişkili sonuçları değerlendirmektir.

Gereç ve Yöntemler: Kliniğimizde Aralık 2015-Ağustos 2016 tarihleri arasında robotik total histerektomi yapılan 16 ardışık hastayı retrospektif olarak inceledik.

Bulgular: On üç (\% 81.25) hastaya benign nedenlerle, 2 (\% 12.5) hastaya endometrium kanseri ve 1 (\% 6.25) hastaya da mikroinvaziv serviks kanseri nedeniyle robotik total histerektomi yapıldı. Hastaların ortalama yaşı $48.75 \pm$ 6.5 , paritesi $2.8 \pm 1.7$, vücut kitle indeksi $28.2 \pm 4.6$, preoperatif hemoglobin $11.6 \pm 1.0 \mathrm{~g} / \mathrm{dl}$, postoperatif hemoglobin $10.3 \pm 1.0 \mathrm{~g} / \mathrm{dl}$, operasyon süresi $162.2 \pm 39.4$ dakika, docking süresi $7.3 \pm 3.3$ dakika, konsol süresi $147 \pm 37.0$ dakika, uterus ağırlıkları $178.8 \pm 98.5 \mathrm{~g}$ ve hastanede kalış süresi $3.6 \pm 1.8$ gün olarak tespit edildi. Üç hastaya postoperative dönemde kan transfüzyonu yapıldı. Myoma uteri nedeniyle opera edilen bir hastada, pelvik yapıların yetersiz vizüalizasyonu nedeniyle laparotomiye geçildi. Hiçbir hastada intraoperative komplikasyon gelişmedi. Postoperatif komplikasyonlar cerrahiyi takiben ilk gün ateş yüksekliğinin görüldüğü astımı olan bir hastayla sinırlıydı.

Sonuç: Robotik histerektomi sonuçları hem hasta hem de cerrah için tatminkardır. Öğrenme eğrisinin tamamlanmasını takiben, robotik total histerektomi laparoskopik histerektomi için önemli bir alternative olabilir. Ancak robot sistemlerinin kurulum, işletim ve bakım maliyetlerinin yüksek olması robotic cerrahinin yaygın kullanımı için hala önemli bir kısıtlılıktır.

Anahtar Sözcükler: Robotik total histerektomi, da Vinci, laparoskopik histerektomi

Geliş Tarihi: 20.12.2016

Kabul Tarihi: 14.02.2017

Address for Correspondence / Yazışma Adresi: Alper Biler, MD Tepecik Training and Research Hospital, Department of Obstetrics and Gynecology, Gaziler Street, No:468, 35120, Izmir, Turkey. E-mail: bileralper@gmail.com

CTelif Hakkı 2017 Gazi Üniversitesi Tıp Fakültesi - Makale metnine http://medicaljournal.gazi.edu.tr/ web adresinden ulaşılabilir. (C) Copyright 2017 by Gazi University Medical Faculty - Available on-line at web site http://medicaljournal.gazi.edu.tr/ doi:http://dx.doi.org/10.12996/gmj.2017.27 


\section{INTRODUCTION}

Hysterectomy is the most common surgical process in the practice of gynecology(1).Traditionally, hysterectomy is performed by three major methods. These involve abdominal, vaginal and various configuration of laparoscopic hysterectomy. Since the first laparoscopic hysterectomy which was made in 1989 by Reich et al.(2), laparoscopic surgery has progressed rapidly along with improvements in technology such as optic and energy modalities. Today, laparoscopic surgery has become the gold standard method both for many benign and malignant gynecological pathologies $(3,4)$.

Together with ongoing innovations in medical devices industry, robotic surgery has become one of the leading developments in the progress of minimally invasive surgery. After approval of robot-assisted technology usage for gynecology by Food and Drug Administration (FDA) in 2005, gynecologic practice has changed severely (5). It is known that robotic surgery has many advantages over conventional laparoscopic techniques in terms of three-dimensional vision, wristed instrumentation that imitates the movements of the human hand, tremor filtration and ergonomic siting of the surgeon $(6,7)$

The specific challenges for robotic surgery can be considered under two categories; cost-related and surgeon-related. The cost of the system which is about \$1-2.3 million without annual maintenance fees and instrumentation is the biggest disadvantage of robotic surgery. On the other hand, surgeonrelated challenges include staying away from bedside, a reason that may contribute to communication difficulties, and lack of haptic feedback. Until learning curve completion, all of these challenges may cause longer initial operation times.

In this study, we aimed to present our initial experience with robotic total hysterectomy (RTH) for various gynecological pathologies and evaluate operation related outcomes.

\section{MATERIAL and METHODS}

\section{Data collection}

A retrospective study was conducted with 16 patients who underwent RTH in the Obstetrics and Gynecology Department of Tepecik Training and Research Hospital between December 2015 and August 2016. The medical records of patients were collected from hospital database. These data consisted of age, body mass index $\left(\mathrm{kg} / \mathrm{m}^{2}\right)$, parity, prior abdominal surgeries, comorbidities, indications for surgery, type of surgery, operative time, docking time, console time, preoperative and postoperative hemoglobin values, need for blood transfusion, intraoperative complications, conversion to laparotomy, uterine weight, length of hospital stay and postoperative complications within 6 weeks of surgery. Operative time was measured from the time of first skin incision to the end of closure. Docking time calculated as the time from the robot was pushed towards the patient to taken until robotic instruments were connected to the trocars placed. Console time was defined as total time that operative surgeon sat at console until completion of the procedure. Length of hospital stay was evaluated from admission to discharge. In addition, uterine weight and complications were monitored and recorded.

\section{Surgical technique}

Before surgery, all patients received mechanical bowel preparation and $2 \mathrm{~g}$ cefazolin (IV) for prophylaxis. General anesthesia was administered via endotracheal intubation. The patients were placed in low dorsal lithotomy position with arms padded and tucked at the side (Figure 1). The bladder was evacuated with a Foley catheter and stomach was emptied with an orogastric tube. A RUMIC uterine manipulator with a Koh Cup ${ }^{\mathrm{TM}}$ colpotomizer (Cooper Surgical; Trumbull, Connecticut, US) was introduced vaginally. All operations were performed by the same surgical team. The da Vinci SI surgical system (Intuitive Surgical, Sunnyvale, CA, USA) was used. Four ports were inserted after pneumoperitoneum was created (Figure 2). A $12 \mathrm{~mm}$ camera port was placed either at or above the umbilicus, depending on the size of the uterus. Two 8-mm robotic trocars were then placed in the right and left lower quadrants, respectively. These ports were placed approximately $10 \mathrm{~cm}$ lateral to the umbilicus. The accessory port was inserted between the camera port and left lower quadrant port. After all ports positioned, patients were placed in steep Trendelenburg position and robot was docked over the patient's right side.
Hysterectomy was performed by using bipolar grasper and monopolar scissors. Hysterectomy procedure included complete removal of uterus, cervix and fallopian tubes with or without concomitant removal of the ovaries. A circumferential vaginal cuff incision was made with monopolar scissors. The cuff closure was performed by a needle driver using intracorporoal suture technique with interrupted figure-of-eight sutures of 0Vicry ${ }^{\circledast}$. Patients were mobilized on the day of surgery. A juicy diet was initiated, and the Foley catheter was removed on the first postoperative day.

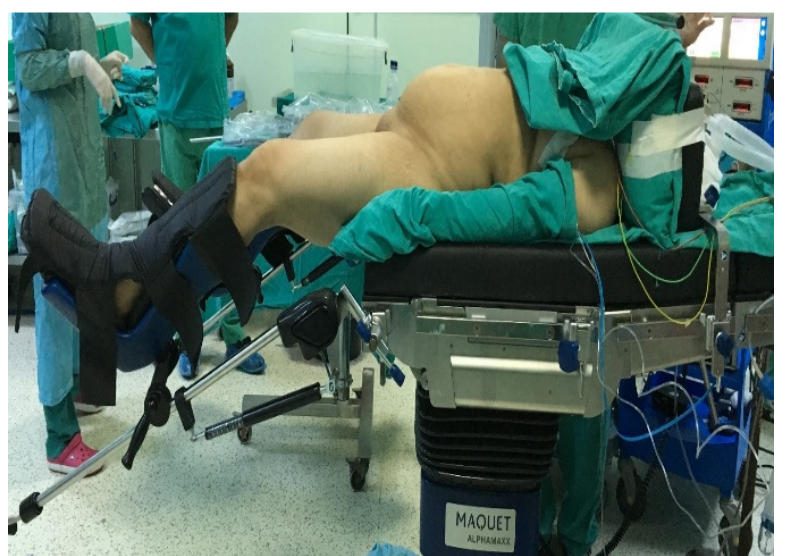

Figure 1. Suitable positioning for robotic cases with patient in low dorsal lithotomy position with arms padded and tucked at the side

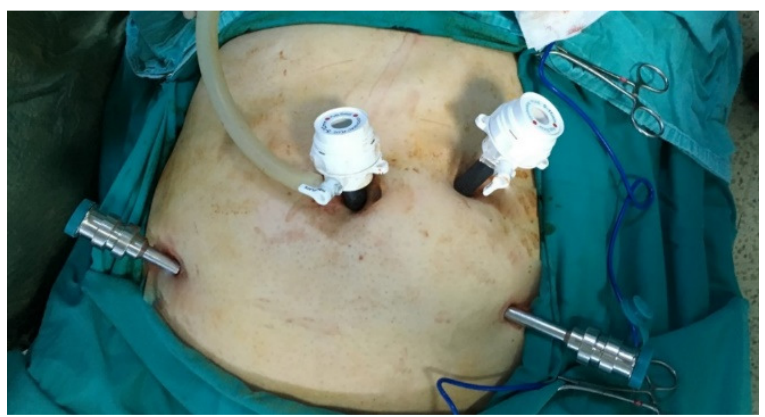

Figure 2. Port placement for RTH withda Vinci SI surgical system. A $12 \mathrm{~mm}$ port for the camera $(A)$ is placed either at or above the umbilicus, depending on the size of the uterus. The lateral ports (B) are $8 \mathrm{~mm}$ da Vinci $C$ ports in the right and left lower quadrants. A $10-12 \mathrm{~mm}$ assist port is placed between the camera port and the left lower quadrant port

\section{Statistical analysis}

Statistical analysis was performed using SPSS (SPSS for Windows version 20.0, SPSS Inc., Chicago, Illinois, USA). Descriptive statistics were used to describe the study. Data were expressed as number and percentages or mean with standard deviations.

\section{RESULTS}

Demographic data and clinical characteristics of patients with RTH were presented in Table 1 . The mean age of patients was $48.7 \pm 6.5$ years, parity was $2.8 \pm 1.7$, and body mass index was $28.2 \pm 4.6 \mathrm{~kg} / \mathrm{m}^{2}$. Three patients had comorbidities (diabetes mellitus [ $n=2]$, asthma $[n=1]$ ). Thirteen patients had no history of prior surgery, whereas one patient had three prior surgeries and two patients had one previous abdominal surgery. RTH was performed for benign indications in $13(81.25 \%)$ patients, endometrial cancer in two patients $(12.5 \%)$, microinvasive cervical cancer in one patient $(6.25 \%)$. One patient underwent pelvic lymph node dissection and one underwent Burch colposuspension along with RTH and bilateral salpingo-oophrectomy. Mean operation time was $162.2 \pm 39.4$ minutes, docking time was $7.3 \pm 3.3$ minutes, and console time was $147 \pm 37.0$ minutes. Mean preoperative and postoperative hemoglobin levels were $11.6 \pm 1.0 \mathrm{~g} / \mathrm{dl}$ and $10.3 \pm 1.0 \mathrm{~g} / \mathrm{dl}$, respectively. Blood transfusion was administered to three patients in the postoperative period. No intraoperative complication was encountered. One patient was converted to laparotomy due to poor visualization of pelvic structures by a large uterus. 
Mean uterine weight was calculated as $178.8 \pm 98.5 \mathrm{~g}$. After surgery, mean duration of hospital stay was $3.6 \pm 1.8$ days. Postoperative complications were limited to one patient with asthma who had fever on the first day following surgery. In that patient, atelectasis was considered as the cause of the fever. The characteristics of 16 patients who underwent RTH were showen in Table

Table 1. Demographicandclinicalcharacteristics of robotic total hysterectomy

\section{Characteristic}

\begin{tabular}{ll}
\hline Age (years), mean \pm SD & $48.75 \pm 6.5$ \\
BMI (kg/m²), mean \pm SD & $28.2 \pm 4.6$ \\
Parity, mean \pm SD & $2.8 \pm 1.7$ \\
Comorbidities, $\mathbf{n}$ (\%) & $3(18.7)$ \\
Priorabdominalsurgeries, $\mathbf{n}$ (\%) & \\
None & $13(81.25)$ \\
$\mathbf{1}$ & $2(12.5)$ \\
$\mathbf{2}$ & 0 \\
$\mathbf{3}$ & $1(6.25)$ \\
Indications, $\mathbf{n}(\%)$ & \\
Benign & $12(75)$ \\
Endometrialcancer & $2(12.5)$ \\
Microinvasivecervicalcancer & $1(6.25)$ \\
Urinaryincontinence & $1(6.25)$ \\
& \\
& \\
Type of procedure, $\mathbf{n}$ (\%) & \\
RTH + BSO & \\
RTH + BS & $9(56.25)$ \\
RTH + BSO + PLND & $2(12.50)$ \\
RTH + BSO + Burch & $1(6.25)$ \\
RTH + right USO + left S & $1(6.25)$ \\
RTH + left USO + right S & $1(6.25)$ \\
TAH+BSO & $1(6.25)$ \\
& $1(6.25)$
\end{tabular}

Operation time (min), mean \pm SD

Docking time $(\mathrm{min})$, mean \pm SD

$7.3 \pm 3.3$

Console time $(\min )$, mean \pm SD

PreoperativeHb (g/dl), mean \pm SD

PostoperativeHb (g/dl), mean \pm SD

$10.3 \pm 1.0$

Blood tranfusion (U), $\mathrm{n}(\%)$

Conversion tolaparotomy, $\mathrm{n}(\%)$

Intraoperativecomplications, $\mathrm{n}(\%)$

0

Postoperativecomplications, $\mathrm{n}$ (\%)

Postoperativefever

Uterineweight $(\mathrm{g})$, mean \pm SD

Length of stay (days), mean \pm SD

\section{DISCUSSION}

Despite well documented benefits of minimally invasive surgery, laparoscopic hysterectomy procedures are not progressing as quickly as technological improvements in this area. One of the reasons is inadequate training of many gynecologic surgeons (8). Furthermore, laparoscopic surgery has a steep and long learning curve. Some studies regarding learning curve of laparoscopic hysterectomy have concluded that 22 to 75 cases were required to reach plateau of learning curve(9-11). On the other hand, the threshold number has been reported as 20 to 50 cases for $\operatorname{RTH}(12,13)$. This plateau can also be reached with a lesser number of cases, depending on the previous laparoscopic experience of surgeons. Sendag et al. analyzed 36 cases of RTH that were performed by one experienced laparoscopic surgeon. They concluded that an experienced laparoscopic surgeon needed nine cases to access proficiency(14).

It is generally accepted that use of the daVinci ${ }^{\circledR}$ system provides better visualization of tissues, better effective dissection, easier and faster colpotomy and intracorporeal suture performance. However, lack of direct access to the patient, especially for uterine manipulation, is one of the major disadvantages of robotic surgery. Lack of haptic feedback is another significant disadvantage. The restrictions of laparoscopic surgery can be overcome by robotic surgery with the help of better ergonomics, wristed instrumentation that moves like a human wrist, tremor filtration, increased dexterity and three-dimensional vision. After FDA approved robot-assisted technology for gynecology in 2005, use of robotic surgery in gynecological practice has rapidly increased(5). In 2005 , use of robotic surgery in hysterectomy cases was $1 \%$, whereas this rate reached $21 \%$ in 2010 (15).

Our mean operating time results were $162.2 \pm 39.4$ minutes which were shorter than first cases described by Reynolds and Advincula(5). They examined sixteen consecutive patients who underwent robot-assisted laparoscopic hysterectomy and found that mean operative time was 242 minutes. However, contrary to many published studies, they calculated operative time from the start of examination under anesthesia rather than from the beginning of robotic surgery. In the studies of Sendag et al. and Bogges et al., mean operative times of patients who underwent robotic hysterectomy were 169 and $122.9 \mathrm{~min}$, respectively $(14,16)$. In mentioned studies, single surgical procedure was applied in patients with only benign pathologies. In our study, pelvic lymph node dissection along with RTH was performed in a patient with endometrium cancer and Burch colposuspension along with RTH was performed in a patient with stress urinary incontinence. No intraoperative complication and only one postoperative complication (6.25\%) which was not associated with procedure were observed. These findings were consistent with previous studies in literature $(14,17)$.

In this study, we found that conversion rate to laparotomy was also similar to prior studies $(17,18)$. Due to poor visualization of pelvic structures, RTH was converted to abdominal hysterectomy in a patient with myoma uteri. The uterus of former patient weighted $410 \mathrm{gr}$. We believe that rates of conversion to laparotomy will be less frequently after completion of learning curve.

In our study, the length of hospital stay was found to be slightly increased when compared to other studies in the literature $(14,16,17)$. One of the possible reasons for this finding is that our hospital is a tertiary reference center and patients had to travel long distances from surrounding settlements. Thus, they want to stayuntil full recovery. Second, hospital-stay charges are relatively inexpensive in our country, and, per the health policy, patients did not pay additional costs for longer hospital stays.

Our study is limited by the retrospective nature of the study design. Furthermore, addition of a control group may increase the power of this investigation. The strength of our study is that all of the procedures were performed by clinicians experienced in laparoscopic surgery. Therefore, procedure related complications were lessened by operator experince.

$\mathrm{BMI}$, body massindex; BS, Bilateralsalpingectomy; BSO, Bilateralsalpingo-oophrectomy; Hb, hemoglobin PLND, pelviclymphnodedissection;

RTH, Robotic total hysterectomy; S, Salpingectomy; $\mathrm{SD}$, standarddeviation; TAH, total abdominalhysterectomy; USO, Unilateralsalpingo-oophrectomy. 


\begin{tabular}{|c|c|c|c|c|c|c|c|c|c|c|c|c|c|c|c|c|}
\hline $\begin{array}{l}\text { Patient } \\
\text { No }\end{array}$ & Age & Indications & & Procedure & & $\begin{array}{l}\text { Operation } \\
\text { time (min) }\end{array}$ & $\begin{array}{l}\text { Docking } \\
\text { time } \\
\text { (min) }\end{array}$ & $\begin{array}{l}\text { Console } \\
\text { Time } \\
\text { (min) }\end{array}$ & $\begin{array}{l}\text { preophb } \\
\text { (g/dl) }\end{array}$ & $\begin{array}{l}\text { Postophb } \\
\text { (g/dl) }\end{array}$ & $\begin{array}{l}\text { Blood } \\
\text { transfusion } \\
\text { (U) }\end{array}$ & $\begin{array}{l}\text { Conversion } \\
\text { tolaparotomy }\end{array}$ & Intraoperativecomplications & Postoperativecomplications & $\begin{array}{l}\text { Uterineweight } \\
\text { (g) }\end{array}$ & $\begin{array}{l}\text { Length } \\
\text { of stay } \\
\text { (days) }\end{array}$ \\
\hline 1 & 48 & $\begin{array}{l}\text { Simple } \\
\text { hyperplasiawithoutatypia }\end{array}$ & & $\begin{array}{l}\text { RTH } \\
\text { BSO }\end{array}$ & + & 160 & 7 & 143 & 10.6 & 8.9 & - & - & - & - & 195 & 4 \\
\hline 2 & 45 & Microinvazivcervicalcancer & & $\begin{array}{l}\text { RTH } \\
\text { BSO }\end{array}$ & + & 235 & 15 & 210 & 12.1 & 10.5 & - & - & - & - & 75 & 3 \\
\hline 3 & 44 & $\begin{array}{l}\text { Simple } \\
\text { hyperplasiawithoutatypia }\end{array}$ & & $\mathrm{RTH}+\mathrm{BS}$ & & 205 & 15 & 180 & 11.7 & 10.5 & - & - & - & - & 135 & 3 \\
\hline 4 & 43 & Abnormaluterinebleeding & & $\begin{array}{l}\text { RTH } \\
\text { right US } \\
+ \text { left S }\end{array}$ & & 148 & 6 & 135 & 10.8 & 9.9 & 1 & - & - & 1 (postoperativefever) & 101 & 10 \\
\hline 5 & 44 & Myomauteri & & $\begin{array}{l}\text { RTH + le } \\
\text { USO } \\
\text { right S }\end{array}$ & $\begin{array}{l}\text { eft } \\
+\end{array}$ & 165 & 5 & 155 & 10.6 & 9.1 & - & - & - & - & 235 & 3 \\
\hline 6 & 39 & $\begin{array}{l}\text { CIN } \\
\text { abnormaluterinebleeding }\end{array}$ & + & $\mathrm{RTH}+\mathrm{BS}$ & & 90 & 6 & 74 & 13.6 & 12.1 & - & - & - & - & 86 & 3 \\
\hline 7 & 44 & Abnormaluterinebleeding & & $\begin{array}{l}\text { RTH } \\
\text { BSO }\end{array}$ & + & 145 & 7 & 138 & 11.3 & 10 & - & - & - & - & 256 & 4 \\
\hline 8 & 54 & $\begin{array}{l}\text { Simple } \\
\text { hyperplasiawithoutatypia }\end{array}$ & & $\begin{array}{l}\text { RTH } \\
\text { BSO }\end{array}$ & + & 100 & 5 & 85 & 11 & 10.3 & - & - & - & - & 254 & 3 \\
\hline 9 & 53 & Myomauteri & & $\begin{array}{l}\text { RTH } \\
\text { BSO }\end{array}$ & + & 155 & 6 & 144 & 13.5 & 11.9 & - & - & - & - & 320 & 4 \\
\hline 10 & 50 & Endometrialcancer & & $\begin{array}{l}\text { RTH } \\
\text { BSO }\end{array}$ & + & 141 & 8 & 128 & 10 & 8 & 2 & - & - & - & 125 & 2 \\
\hline 11 & 54 & Endometrialcancer & & $\begin{array}{l}\text { RTH } \\
\text { BSO } \\
\text { PLND }\end{array}$ & $\begin{array}{l}+ \\
+\end{array}$ & 148 & 4 & 136 & 11.8 & 10.8 & - & - & - & - & 184 & 4 \\
\hline 12 & 54 & $\begin{array}{l}\text { Simple } \\
\text { hyperplasiawithoutatypia }\end{array}$ & & $\begin{array}{l}\text { RTH } \\
\text { BSO }\end{array}$ & + & 149 & 4 & 135 & 11.1 & 10.6 & - & - & - & - & 138 & 2 \\
\hline 13 & 54 & $\begin{array}{l}\text { Abnormaluterinebleeding } \\
\text { stressurinaryincontinence }\end{array}$ & + & $\begin{array}{l}\text { RTH } \\
\text { BSO } \\
\text { Burch }\end{array}$ & $\begin{array}{l}+ \\
+\end{array}$ & 215 & 6 & 201 & 12.1 & 11.5 & 1 & - & - & - & 121 & 3 \\
\hline 14 & 46 & Myomauteri & & $\begin{array}{l}\text { TAH } \\
\text { BSO }\end{array}$ & + & & & & 12.5 & 11.4 & 0 & 1 & 0 & 0 & 416 & 3 \\
\hline 15 & 43 & Abnormaluterinebleeding & & $\begin{array}{l}\text { RTH } \\
\text { BSO }\end{array}$ & + & 187 & 9 & 168 & 11.4 & 9.9 & 0 & 0 & 0 & 0 & 181 & 3 \\
\hline 16 & 65 & Postmenopozalvaginalbleeding & & $\begin{array}{l}\text { RTH } \\
\text { BSO }\end{array}$ & + & 190 & 7 & 173 & 12.7 & 10.5 & 0 & 0 & 0 & 0 & 40 & 3 \\
\hline
\end{tabular}

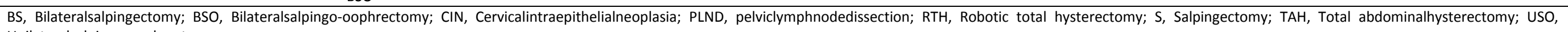
Unilateralsalpingo-oophrectomy 


\section{CONCLUSION}

Our results of RTH were found to be satisfactory for both patient and surgeon. After completion of the learning curve, RTH could be an important alternative method for laparoscopic hysterectomy. However, installation of robotic systems, operating and maintenance costs still remain as crucial limitations for the widespread use of robotic surgery. Further studies on the improvement of robotic technology and its costs are needed.

\section{Conflict of interest}

No conflict of interest was declared by the authors.

\section{REFERENCES}

1. Garry R. The future of hysterectomy. BJOG 2005;112:133-9.

2. Reich H, De Caprio J, Mac Glynn F. Laparoscopic hysterectomy. J Gynecol Coll Surg 1989;5:213.

3. Desimone CP, Ueland FR. Gynecologic laparoscopy. SurgClin North Am 2008;88:319-41.

4. He H, Zeng D, Ou H, Tang Y, Li J, Zhong H. Laparoscopic treatment of endometrial cancer: systematic review. J Minim Invasive Gynecol 2013;20:413-23.

5. Reynolds RK, Advincula AP. Robot-assisted laparoscopic hysterectomy: technique and initial experience. Am J Surg 2006;191:555-60.

6. Visco AG, Advincula AP. Robotic gynecologic surgery. ObstetGynecol 2008;112:1369-84.

7. Magrina JF, Kho RM, Weaver AL, Montero RP, Magtibay PM. Robotic radical hysterectomy: comparison with laparoscopy and laparotomy. GynecolOncol 2008;109:86-91.

8. Wattiez A, Cohen SB, Selvaggi L. Laparoscopic hysterectomy. Cur OpinObstetGynecol 2002;14:417-22.
9. Garry R, Fountain J, Mason S, Hawe J, Napp V, Abbott J, et al. The eVALuate study: two paralel randomized trials, one comparing laparoscopic with abdominal hysterectomy, the other comparing laparoscopic with vaginal hysterectomy. BMJ 2004;328:1229-36.

10. Twijnstra AR, Blikkendaal MD, Kolkman W, Smeets MJ, Rhemrev JP, Jansen FW. Implementation of laparoscopic hysterecomy: maintenance of skills after a mentorship program. GynecolObstet Invest 2010;70:173-8.

11. Terzi H, Biler A, Demirtas O, Guler OT, Peker N, Kale A. Total laparoscopic hysterectomy: Analysis of the surgical learning curve in benign conditions. Int J Surg 2016;35:51-7.

12. Lenihan JP, Jr, Kovanda C, Seshadri-Kreaden U. What is the learning curve for robotic assisted gynecologic surgery? J Minim Invasive Gynecol 2008;15:589-94.

13. Pitter $M C$, Anderson $P$, Blissett $A$, Pemberton N. Robotic-assisted gynaecological surgery - establishing training criteria: minimizing operative time and blood loss. Int J Med Robot 2008;4:114-20.

14. Sendag F, Zeybek B, Akdemir A, Ozgurel B, Oztekin K. Analysis of the learning curve for robotic hysterectomy for benign gynaecological disease. Int J Med Robotics Comput Assist Surg 2014;10:275-9.

15. Luciano AA, Luciano DE, Gabbert J, Seshadri-Kreaden U. The impact of robotics on the mode of benign hysterectomy and clinical outcomes. Int J Med Robotics Comput Assist Surg 2016;12:114-24.

16. Boggess JF, Gehrig PA, Cantrell L, Shafer A, MendivilA, Rossi E, et al. Perioperative outcomesof robotically assisted hysterectomy for benign cases withcomplex pathology. ObstetGynecol 2009;114:585-93.

17. Fiorentino RP, Zepeda MA, Goldstein BH, John CR, Rettenmaier MA. Pilot study assessing robotic laparoscopic hysterectomy and patient outcomes. J Minim Invasive Gynecol 2006;13:60-3.

18. Payne TN, Dauterive FR. A comparison of total laparoscopic hysterectomy to robotically assisted hysterectomy: surgical outcomes in a community practice. J Minim Invasive Gynecol 2008;15:286-91. 